\title{
Depolarization and Neurotransmitter Regulation of Vasopressin Gene Expression in the Rat Suprachiasmatic Nucleus In Vitro
}

\author{
Milan Rusnak, ${ }^{\star}$ Zsuzsanna E. Tóth ${ }^{\star}$ Shirley B. House, and Harold Gainer \\ Molecular Neuroscience Section, Laboratory of Neurochemistry, National Institute of Neurological Disorders and Stroke, National Institutes of Health, \\ Bethesda, Maryland, 20892
}

\begin{abstract}
Vasopressin (VP) transcription in the rat suprachiasmatic nucleus (SCN) in organotypic culture was studied by in situ hybridization histochemistry using an intron-specific VP heteronuclear RNA probe. The circadian peak of VP gene transcription in the SCN in vitro is completely blocked by a $2 \mathrm{~h}$ exposure to tetrodotoxin (TTX) in the culture medium, and this TTX inhibition of VP gene transcription is reversed by exposure of the SCN to either forskolin or potassium depolarization. This suggests that an intrinsic, spontaneously active neuronal mechanism in the SCN is responsible for the cAMP- and depolarization-dependent pathways involved in maintaining peak VP gene transcription. In this paper, we evaluate a variety of neurotransmitter candidates, membrane receptors, and signal-transduction cascades that might constitute the mechanisms responsible for the peak of VP gene transcription. We find that vasoactive intestinal peptide (VIP) and a VPAC2 (VIP receptor subtype 2) receptor-specific agonist, Ro-25-1553, are the most effective ligands tested in evoking a cAMP-mitogen-activated protein kinase signal transduction cascade leading to an increase in VP gene transcription in the SCN. In addition, a second independent pathway involving depolarization activating L-type voltage-gated calcium channels and a Cadependent kinase pathway [inhibited by KN62 (1-[N,O-bis(5-isoquinolinesulphonyl)- $N$-methyl-L-tyrosyl]-4-phenylpiperazine)] rescues VP gene transcription in the presence of TTX. In the absence of TTX, these independent pathways appear to act in a cooperative manner to generate the circadian peak of VP gene transcription in the SCN.
\end{abstract}

Key words: SCN; organotypic cultures; vasopressin; circadian rhythm; gene regulation; VIP; VPAC2 receptor

\section{Introduction}

The suprachiasmatic nucleus (SCN) of the hypothalamus contains the primary circadian pacemaker that controls various physiological and behavioral rhythms (Gillette and Tischkau, 1999; Reppert and Weaver, 2001, 2002). Investigations into the molecular nature of the clock in the mammalian SCN have revealed a variety of "clock genes" involved in autoregulatory transcription and translation feedback loops generating the circadian rhythms (Reppert and Weaver, 2001, 2002). The rodent SCN contains distinct types of neurons, in the ventrolateral "core" and the dorsomedial "shell" (Moore and Silver, 1998; Moore et al.,

\footnotetext{
Received Aug. 28, 2006; revised Nov. 27, 2006; accepted Nov. 28, 2006.

This work was supported by the Intramural Research Program of the National Institutes of Health-National Institute of Neurological Disorders and Stroke. We thank Dr. Thomas Sherman (Georgetown University Medical School, Washington, DC) for his gift of the intron-specific VP riboprobe and Dr. Patrick Robberrecht (Free University of Brussels, Brussels, Belgium) for his gifts of the specific VPAC2 agonist Ro-25-1553 and antagonist PG 99-465.

${ }^{*} M$.R. and Z.E.T. contributed equally to this work.

Correspondence should be addressed to Dr. Harold Gainer, National Institute of Neurological Disorders and Stroke, National Institutes of Health, Building 36, Room 4D-18, Bethesda, MD 20892. E-mail: gainerh@ninds.nih.gov.

M. Rusnak's present address: Laboratory of Neurochemistry, Department of Biochemistry and Molecular and Cellular Biology, Georgetown University Medical Center, The Research Building, Room W222, 3970 Reservoir Road NW, Washington, DC 20007.

Z. E. Tóth's present address: Semmelweis University, Department of Anatomy, Histology, and Embryology, Laboratory of Neuromorphology, 1094 Budapest, Tuzoltó utca 58, Hungary.

D01:10.1523/JNEUROSCI.3739-06.2007

Copyright $\odot 2007$ Society for Neuroscience $\quad$ 0270-6474/07/270141-11\$15.00/0
}

2002). Only neurons in the shell are considered endogenous oscillators, whereas neurons in the core are not intrinsically rhythmic but are retinoreceptive (Antle et al., 2003). This model of SCN organization posits that signals from the retinorecipient neurons in the core synchronize and determine the phases of the rhythmic activity of neurons in the shell (Antle et al., 2003; Yamaguchi et al., 2003; Aton and Herzog, 2005). Although there are other views of SCN organization (Morin et al., 2006), there is general agreement that, in rodents, the vasopressinergic neurons are predominantly located in dorsomedial SCN, and the vasoactive intestinal peptide (VIP)- positive neurons are in the ventral SCN (Morin and Allen, 2006; Morin et al., 2006).

The vasopressin (VP) neuronal phenotype acts to regulate electrical activity within the SCN (Ingram et al., 1996, 1998) and also sends efferent projections to other regions of the hypothalamus to regulate various endocrine rhythms (Kalsbeek and Buijs, 2002; Perreau-Lenz et al., 2004). VP gene expression in the SCN exhibits circadian rhythms (Reppert and Weaver, 2001; Yambe et al., 2002), and an E-box element (CACGTC) in the VP promoter binds the Clock:Bmal-1 (brain and muscle Arnt-like protein 1) heterodimer and is essential for the circadian expression of the VP gene in the SCN (Jin et al., 1999). In a previous study, we showed that a robust circadian pattern of VP transcription is maintained in organotypic slices and that the daytime peak in VP gene expression is completely blocked by $2 \mathrm{~h}$ of exposure of the 
SCN to tetrodotoxin (TTX) in the culture medium (Arima et al., 2002). We also found that this TTX-inhibition of VP gene expression could be reversed by the addition of the adenylate cyclase activator forskolin to the medium.

We hypothesize that the normal spontaneous neural activity in the SCN activates a VPAC2 (VIP receptor subtype 2) receptor on the VP neuron, which generates intracellular cAMP, and then activates a mitogen-activated protein (MAP) kinase pathway, leading to the peak of VP gene transcription. We present evidence here that the most effective stimuli to reverse the TTX inhibition were the VIP and the VPAC2-receptor-specific ligand Ro-251553 (Gourlet et al., 1997) and that both activated a cAMP-MAP kinase pathway, which increased VP gene transcription. In addition, we found that potassium depolarization could rescue the VP gene transcription from TTX inhibition by activation of a calcium/calmodulin-dependent kinase (CaMK) pathway in the SCN.

\section{Materials and Methods}

\section{Slice-explant culture procedures}

Sprague Dawley rat pups (postnatal day 6) were decapitated, and the brains were quickly removed. All procedures were similar to those described previously (House et al., 1998; Arima et al., 2002) and were performed in accordance with the National Institutes of Health Guidelines on the Care and Use of Animals and an animal study protocol approved by the National Institute of Neurological Disorders and Stroke Animal Care and Use Committee. Hypothalamic tissue blocks were sectioned (350 $\mu \mathrm{m}$ ) on a McIlwain tissue slicer, and four coronal slices containing the SCN, supraoptic nucleus, and paraventricular nucleus were separated in $4^{\circ} \mathrm{C}$ Gey's balanced salt solution (Invitrogen, Carlsbad, CA) enriched with glucose $(5 \mathrm{mg} / \mathrm{ml})$ and then placed on Millicell-CM filter inserts (pore size of $0.4 \mu \mathrm{m}$, diameter of $30 \mathrm{~mm}$; Millipore, Bedford, MA). Each filter insert was placed in a Petri dish $(35 \mathrm{~mm})$, containing $1.2 \mathrm{ml}$ of culture medium that wet the exposed surfaces of the explants but did not submerge them. Incubation of the cultures was stationary in $5 \% \mathrm{CO}_{2}$ enriched air at $35^{\circ} \mathrm{C}$ for a total of $17 \mathrm{~d}$. The culture medium was replaced every 2-3 d.

\section{Media and incubations}

The serum-containing medium (SCM) was composed of Eagle's basal medium with Earle's salts (50\%), heat-inactivated horse serum $(25 \%)$, HBSS $(25 \%)$, glucose $(0.5 \%)$, and penicillin/streptomycin $(50 \mathrm{U} / \mathrm{ml}$ and $50 \mathrm{cg} / \mathrm{ml}$, respectively). The osmotic pressure of the standard medium was $314 \mathrm{mOsm} / \mathrm{L}$. Serum-free media (SFM) contained 91\% Neurobasal A medium, 2\% B27 supplement, $0.5 \%$ glucose, 1 mm sodium pyruvate, 2 mM glutaMAX I, 10 mM HEPES, $0.075 \%$ sodium bicarbonate, and penicillin/streptomycin $(50 \mathrm{U} / \mathrm{ml}$ and $50 \mathrm{cg} / \mathrm{ml}$, respectively). All ingredients for both types of media were from Invitrogen.

\section{Experimental treatments}

The hypothalamic slices were routinely cultured in SCM for $13 \mathrm{~d}$, which was then replaced by defined SFM for 4 additional days. Experiments were done on day 17 in either the absence or presence of $2.5 \mu \mathrm{M}$ (Sigma, St. Louis, MO). This in vitro incubation period was based on our previous findings (Arima et al., 2002), which showed that the circadian peak of gene expression occurred at midday after $17 \mathrm{~d}$ in vitro (div). When the cultures were to be analyzed for c-Fos expression, the TTX was added to the media $2 \mathrm{~h}$ before the experimental reagents were added, which was $4 \mathrm{~h}$ before the termination of the experiment by fixation. To study the effects of activator and inhibitor agents on the VP heteronuclear RNA (hnRNA) expression by in situ hybridization histochemistry (ISHH), in the presence of TTX, the TTX and inhibitory reagents were added $1 \mathrm{~h}$ before the addition of the stimulatory experimental reagents (e.g., glutamate agonists, $\mathrm{KCl}$, etc.; see below), which were added $2 \mathrm{~h}$ before the termination of the experiment by fixation. Our choice of $2 \mathrm{~h}$ poststimulation as the time to evaluate the VP hnRNA changes in response to stimulation in vitro was based on the results of a previous time course study on the VP gene expression responses of magnocellular and parvocellular neurons in vivo (Ma and Aguilera, 1999), which showed this time to be optimum. In addition, in our previous study on the SCN (Arima et al., 2002), we found that the $2 \mathrm{~h}$ time point was effective in evaluating VP hnRNA changes in response to stimulation in vitro.

\section{Reagents}

Activation by potassium depolarization and $G A B A_{A}$ receptor inhibition. Slices were depolarized by $50 \mathrm{~mm} \mathrm{KCl}$, and $10 \mu \mathrm{m}$ bicuculline (Sigma) was used to remove $\mathrm{GABA}_{\mathrm{A}}$ inhibition.

Glutamate agonists and serotonin. Excitatory amino acid agonists were diluted in sterile water and were used at $50 \mu \mathrm{M}$ each in the SFM: NMDA, AMPA, 3,5-dihydroxyphenylglycine (DHPG), and kainate. All of these substances were obtained from Sigma. Serotonin (Sigma) was diluted in sterile water and used at a concentration of $10 \mu \mathrm{M}$.

VIP, pituitary adenylate cyclase-activating polypeptide, and related reagents. VIP obtained from Tocris Cookson (Ellisville, MO) was diluted in sterile water and used at a concentration of $300 \mathrm{~nm}$. Pituitary adenylate cyclase-activating polypeptide (PACAP)-38 was obtained from Bachem Bioscience (King of Prussia, PA) and was used at 100 or $200 \mathrm{~nm}$. The PACAP6-38 antagonist was obtained from Bachem Bioscience and was used at 5 $\mu$ M. The VPAC2-specific agonist Ro-25-1553 (Gourlet et al., 1997) and antagonist PG-99-465 (Moreno et al., 2000) were obtained as gifts from Prof. Dr. Patrick Robberrecht (Free University of Brussels, Brussels, Belgium). The stock solutions of these reagents were dissolved in DMSO and used at 10-100 and 10-500 nM, for Ro-25-1553 and PG-99-465, respectively.

Forskolin. Second-message activation of adenylate cyclase was produced by the addition of $10 \mu \mathrm{M}$ forskolin (Sigma) to the medium. The cell-permeable cAMP antagonist adenosine $3^{\prime}, 5^{\prime}$ cyclic monophosphorothioate, 8-bromo, Rp-isomer, sodium salt (Rp-8-Br-cAMPS) was obtained from Calbiochem (San Diego, CA) and used at a concentration of $200 \mu \mathrm{M}$.

Protein kinase inhibitors. The protein kinase A inhibitor H89 ( $N-[2-(p-$ bromocinnamyl)amino)ethyl]-5-isoquinolinesulfonamide $2 \mathrm{HCl}$ ) and the MAPK kinase (MEK) inhibitors PD98059 (2'-amino-3'-methyoxyflavone) and U0126 [1,4-diamino-2,3-dicyano-1,4-bis(o-aminophenylthio)butadiene] were obtained from Calbiochem, were prepared as stock solutions in DMSO, and used at concentrations of 5,75 , and $10 \mu \mathrm{M}$, respectively, in the culture media. The calmodulin kinase inhibitors KN62 (1-[N,O-bis(5isoquinolinesulphonyl)- $N$-methyl-L-tyrosyl]-4-phenylpiperazine), KN92 [2-[N-(4-methoxybenzenesulfonyl)] amino- $N$-(4-chlorocinnamyl)- $N$ methylbenzylamine phosphate], and KN93 (2-[N-(2-hydroxyethyl)]-N-(4methoxybenzenesulfonyl)amino- $N$-(4-chlorocinnamyl)- $N$-methylbenzylamine) were obtained from Calbiochem and used at 60,10, and $10 \mu \mathrm{M}$, respectively.

Calcium channel blockers. Cadmium ion (nonspecific calcium channel blocker) and nimodipine (calcium L-channel blocker) were used at concentrations of 200 and $5 \mu \mathrm{M}$, respectively, and thapsigargin $(0.2 \mu \mathrm{M})$ was used to prevent mobilization of intracellular calcium stores. All of these chemicals were obtained from Sigma.

When stock solutions of the reagents were dissolved in DMSO, equivalent amounts of DMSO were added to the control groups in the experiments.

\section{Immunohistochemistry}

The experiments were terminated by fixation of the explants on the filters in $4 \%$ formaldehyde in PBS for $1 \mathrm{~h}$ for immunohistochemistry (IHC). The fixed slices were rinsed three times for $10 \mathrm{~min}$ in PBS, placed into cryoprotectant medium (Watson et al., 1986), and stored at $4^{\circ} \mathrm{C}$ until used for immunohistochemical analysis. To immunostain the explants, the filters containing the fixed slices were excised from the inserts using a scalpel, placed in Netwell carriers, and rinsed in PBS. The nonspecific binding was blocked by incubation in $10 \%$ normal goat serum $/ 0.3 \%$ Triton X-100 for $2 \mathrm{~h}$. For identifying c-fos immunoreactivity, slices were first incubated with a rabbit antiserum against c-fos (Ab-5, catalog \#PC38; Calbiochem) at a dilution of 1:20,000, which was then visualized by AlexaFluor 594-conjugated goat anti-rabbit secondary antibody (Invitrogen) at 1:500 dilution. To identify VP neurons, PS41, a mouse antibody against VP-associated neurophysin (Ben-Barak et al., 1985), was used at a dilution of 1:100 in overnight incubations at $4^{\circ} \mathrm{C}$, followed by 

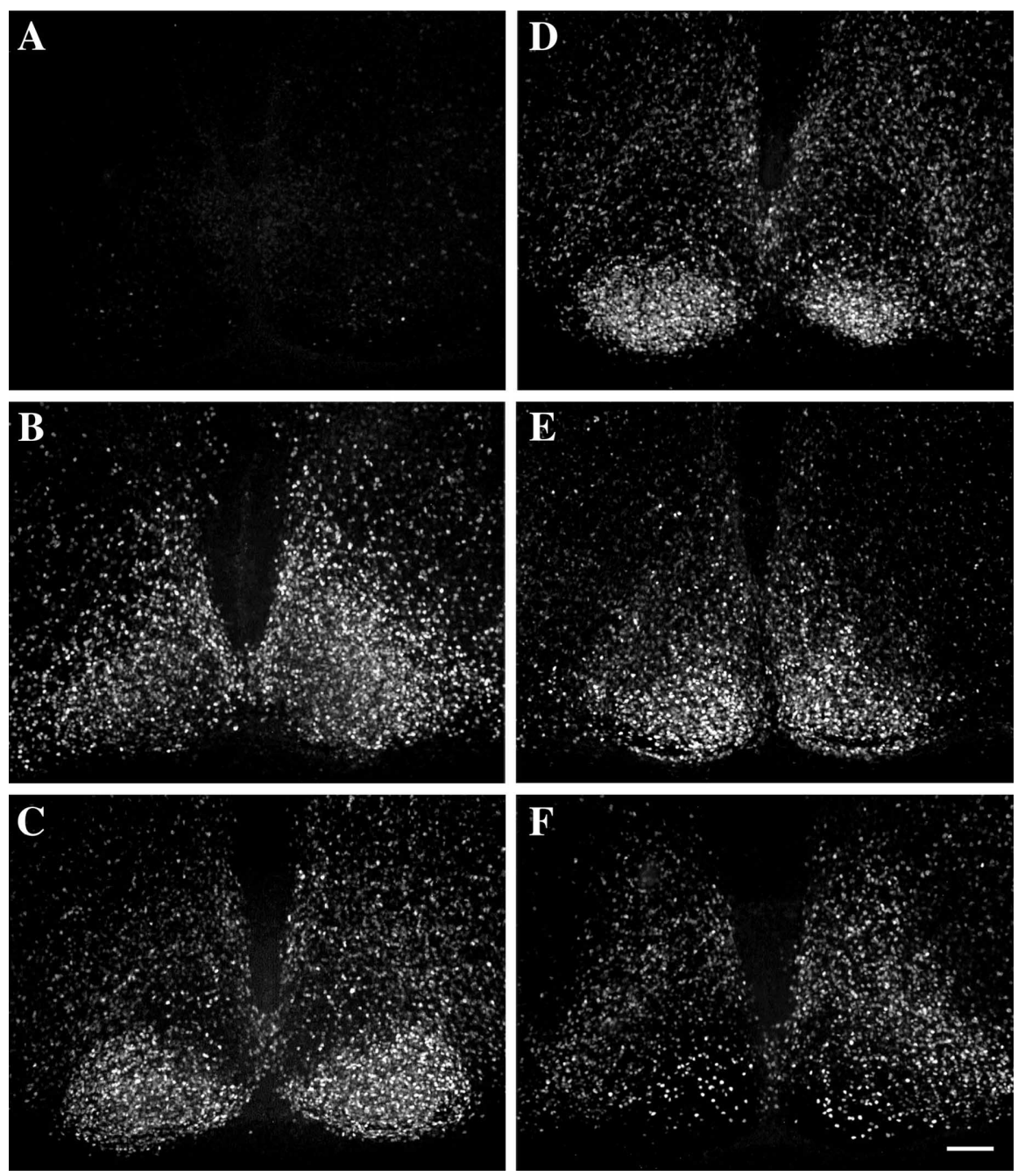

Figure 1. Patterns of glutamate agonist-stimulated c-Fos expression in the SCN in vitro in the absence $(\boldsymbol{A}, \boldsymbol{B})$ and presence $(\boldsymbol{C}-\boldsymbol{F})$ of $2.5 \mu \mathrm{m}$ TTX. Representative c-Fos-IR patterns are shown for unstimulated (control) slices $(\boldsymbol{A})$, slices stimulated by $50 \mu \mathrm{M}$ NMDA in the absence of TTX $(\boldsymbol{B})$, and in slices after stimulation by $50 \mu \mathrm{m}$ each of various ionotropic glutamate agonists $(\boldsymbol{C}-\boldsymbol{F})$, such as NMDA $(\boldsymbol{C}), \operatorname{AMPA}(\boldsymbol{D})$, and kainic acid $(\boldsymbol{E})$ and by the metabotropic glutamate agonist DHPG $(\boldsymbol{F})$ in the presence of TTX in the media. Scale bar, $100 \mu \mathrm{m}$. Note the differences in patterns of c-Fos-IR after NMDA stimulation in the absence $(\boldsymbol{B})$ versus that seen in the presence $(\boldsymbol{C})$ of TTX and the robust ventral labeling produced by all three ionotropic agonists $(\boldsymbol{C}-\boldsymbol{E})$ in contrast to the evenly distributed pattern produced by the metabotropic glutamate agonist $(\boldsymbol{F})$. See Results

washes in PBS, and a $2 \mathrm{~h}$ incubation in peroxidase-conjugated goat antimouse secondary antibody (1:500, ABC Vectastain kit; Vector Laboratories, Burlingame, CA) for DAB staining. To identify VP neurons by immunofluorescence, PS41 was used at dilution of 1:20 in overnight incubations at $4^{\circ} \mathrm{C}$, followed by washes in PBS and a $2 \mathrm{~h}$ incubation in AlexaFluor 488-conjugated goat anti-mouse secondary antibody (Invitrogen) at a 1:500 dilution. Slides were viewed under an epifluorescence microscope (Labophot; Nikon, Tokyo, Japan) or a laser scanning confocal microscope (LSH 410; Zeiss, Oberkochen, Germany) equipped with appropriate filter sets.

\section{In situ hybridization histochemistry}

Riboprobes. The VP (735 bp fragment of intron 1 of the rat VP gene subcloned into pGEM-3 and linearized by HindIII) intronic probe used to detect and quantify VP hnRNA was a gift from Dr. Thomas Sherman (Georgetown University Medical School, Washington, DC) (Herman et al., 1991).

Hybridization. ISHH procedures were similar to those described previously (Arima et al., 2002; Mutsuga et al., 2004). Cultured slices were fixed on the filters for $40 \mathrm{~min}$ in $4 \%$ buffered formaldehyde, washed in PBS, rinsed with sterile water, and then carefully removed from the filters and mounted onto positively charged slides. After air drying, slides were placed on a warm plate $\left(37^{\circ} \mathrm{C}\right)$ for $15 \mathrm{~min}$ and stored at $-80^{\circ} \mathrm{C}$ until used. Before hybridization, the slides were defrosted, air dried for 10 min, and then rinsed in PBS. Slides were placed in $700 \mathrm{ml}$ of $1 \times$ Citra Plus (Biogenix, San Ramon, CA) solution, $\mathrm{pH}$ 6.0, and microwaved for $5 \mathrm{~min}$ at $630 \mathrm{~W}$ to bring to boil and for an additional $5 \mathrm{~min}$ rotating at $450 \mathrm{~W}$. Slides were cooled for $5 \mathrm{~min}$ in ice-cold $70 \%$ ethanol and rinsed in sterile water. The slides were then acetylated for $20 \mathrm{~min}$ with $0.25 \%$ acetic anhydride in $0.1 \mathrm{~m}$ triethanolamine- $\mathrm{HCl}, \mathrm{pH} 8.0$, rinsed in $2 \times$ SSC diluted from $20 \times$ SSC buffer, $\mathrm{pH} 7.0(0.3 \mathrm{~m}$ trisodium citrate and $0.3 \mathrm{~m}$ $\mathrm{NaCl})$, dehydrated in ethanol $(70,80$, and $95 \%$ for $3 \mathrm{~min}, 100 \% 5 \mathrm{~min}$ ), delipidated for $5 \mathrm{~min}$ in chloroform, placed for $5 \mathrm{~min}$ in $100 \%$ and for $3 \mathrm{~min}$ in $95 \%$ ethanol, and finally air dried. Slides were hybridized overnight at $55^{\circ} \mathrm{C}$ with $2 \times 10^{6} \mathrm{cpm}$ of UTP ${ }^{35}$ S-labeled antisense probes in $80 \mu \mathrm{l} /$ slide hybridization buffer [ $50 \%$ formamide, $250 \mathrm{~mm}$ Tris- $\mathrm{HCl}, \mathrm{pH}$ 7.4, $1 \mathrm{~mm}$ EDTA, pH 8.0, 300 mm NaCl, 10\% dextran sulfate, $1 \times$ Denhardt's solution, $25 \mathrm{mg} / \mathrm{ml}$ yeast tRNA, $100 \mu \mathrm{g} / \mathrm{ml}$ salmon sperm DNA, 250 $\mu \mathrm{g} / \mathrm{ml}$ total yeast RNA, $100 \mathrm{~mm}$ dithiotreitol (DTT), $0.1 \%$ sodium thiosulfate, and $0.1 \%$ SDS]. After hybridization, the coverslips were removed in $4 \times$ SSC/ 1 mM DTT (Fisher Scientific, Pittsburgh, PA), and the slides were rinsed four times for $5 \mathrm{~min}$ in $4 \times \mathrm{SSC} / 1 \mathrm{~mm} \mathrm{DTT}$, and then they were placed in $20 \mu \mathrm{g} / \mathrm{ml}$ RNase A (Sigma) buffer at $37^{\circ} \mathrm{C}$ for $60 \mathrm{~min}$. After $5 \mathrm{~min}$ washes in $2 \times \mathrm{SSC} / 1 \mathrm{~mm}$ DTT, $1 \times \mathrm{SSC} / 1 \mathrm{~mm}$ DTT, and $0.5 \times$ SSC/ 1 mм DTT at room temperature, slides were placed two times for 40 min at $65^{\circ} \mathrm{C}$ in $0.1 \times \mathrm{SSC} / 1 \mathrm{~mm}$ DTT. Slides were then dehydrated in ethanol $(70,80,95$, and $100 \%$ for $1 \mathrm{~min}$ each), air dried, and apposed to autoradiographic films (Biomax MR; Eastman Kodak, Rochester, NY), which were developed after appropriate times of exposure. Slides were also coated with autoradiographic emulsion, and, after $9-12 \mathrm{~d}$ of incubation in dark dry boxes at $4^{\circ} \mathrm{C}$, the silver grains were developed using Kodak Dektol (Biomax MR; Eastman Kodak) at $18^{\circ} \mathrm{C}$. In other experiments, after the washes, the sections were apposed to a low energy storage phosphor screen (Amersham Biosciences, Piscataway, NJ) overnight and developed using a phosphorimager (Storm 860; Amersham Biosciences).

\section{Analysis and quantification of ISHH}

In some experiments, quantification was done on autoradiographic film images. VP hnRNA levels were quantified for the integrated optical density (optical density $\times$ area) measurements over the brain slices from each rat, as described previously (Rusnak and Gainer, 2005). In other experiments, the average densities and unit areas from the $\mathrm{SCN}$ recorded on the phosphorimager were measured using the Image Quant software version 5.2 (Amersham Biosciences), as described previously (Mutsuga et al., 2004, 2005). Statistical significance of differences between groups was calculated by one-way ANOVA followed by Fisher's PLSD test, using the Statview 5.0 (SAS Institute, Cary, NC) program. Experiments were repeated, and results are expressed as the mean \pm SEM of pooled data. Differences between groups were considered statistically significant when $p<0.05$.

\section{Results}

The principal assay used in this study measures VP hnRNA and, hence, provides information about the regulation of gene expres- 
sion specifically in the VP neuronal phenotype in the SCN. The pharmacological interventions that we use here are predominantly performed in the presence of TTX, an inhibitor of voltage-dependent sodium channels, which is known to completely block spike activity in the SCN in vitro (Shibata and Moore, 1993; Yamaguchi et al., 2003). Under these conditions, virtually all neuronal interactions are inhibited in the SCN, and, hence, the neurotransmitters and other reagents that are used in this study to activate the SCN neurons should be acting directly on receptors of the VP neurons in the cultured slice. Before examining the effects of these various activating agents on VP hnRNA levels, we used an independent assay to ensure that the concentrations of the pharmacological agents used were adequate to activate the SCN neurons in TTX. For this purpose, we used the c-fos gene expression as the marker of neuronal activation. Illustrations of this strategy for several of the neurotransmitters used for activation of the SCN neurons are shown in Figures 1-3.

\section{A pharmacological approach to the study of regulated gene expression in the SCN}

SCN neurons are known to contain various glutamate afferent inputs and receptor subunits (Eyigor et al., 2001; Hannibal, 2002), and we wanted to determine which, if any, of the various agonists could directly effect the expression initially of $c$-fos and subsequently VP of hnRNA in the cultured SCN slices. The data in Figure 1 illustrate the results of activation of neurons in the cultured SCNs by various glutamate-receptor ligands. Under control conditions, in the absence of TTX, there is very little c-Fos-IR evident in the SCN (Fig. $1 A$ ), whereas in $50 \mu \mathrm{M}$ NMDA, there is significant expression of c-Fos-IR in the cultured SCN (Fig. $1 B$ ). As noted above, this response in the absence of TTX could be relatively nonspecific, in that NMDA receptors on other neurons in the slice could be activated by NMDA and these neurons could in turn activate the VP neurons in the SCN indirectly via an unknown neurotransmitter. To minimize this possibility, all subsequent experiments (Figs. $1 C-F$ ) were performed in the presence of TTX. In this manner, the transcriptional responses to specific agonists, such as NMDA, are restricted only to those cells that have NMDA receptors, because all sodium-dependent electrical activity leading to evoked synaptic activation in the cultured slice is eliminated. Figure $1 C$ illustrates the expression of c-Fos-IR in the cultured SCN after NMDA receptor activation in the presence of TTX. Under these circumstances, there is a very different pattern of c-Fos-IR evoked, with the greatest intensity of c-fos induction being in the ventral SCN, in which the retinoreceptive VIP and gastrin-releasing peptide neurons are located (Moore et al., 2002). A similar pattern of c-Fos-IR was found in the cultured SCNs in TTX when they are exposed to other ionotropic agonists, e.g., AMPA (Fig. 1D) and kainate (Fig. 1E). It is interesting that this region of the SCN, which is normally richly innervated by glutamatergic retinal fibers in vivo (Moore and Silver, 1998; Hannibal, 2002; Moore et al., 2002), still contains densely concentrated ionotropic glutamate receptors even after
$17 \mathrm{~d}$ of denervation. There is also significant c-Fos-IR evoked by the ionotropic agonists (in TTX) in the dorsal (VP-expressing) regions of the SCN, suggesting that these cells can also be directly affected by glutamatergic inputs. In contrast, when the metabotropic agonist DHPG was used, there appeared to be a greater c-Fos-IR induced in the dorsal as opposed to the ventral region of the SCN (Fig. $1 F$ ).

In a previous report (Arima et al., 2002), we showed that the inhibition of VP transcription in the cultured SCN by TTX could be reversed by the application of forskolin to the SCN in vitro. This suggested that an important neural input to the VP neurons in the SCN that could be responsible for the activation of VP transcription that was blocked by the TTX might be acting via a G-protein-coupled receptor to increase intracellular cAMP. VIP fibers are known to innervate the VP neurons in the dorsomedial region of the SCN (Moore et al., 2002), which also contain VIP2 (or VPAC2) receptors (Usdin et al., 1994). VPAC2 receptors are coupled to adenylate cyclase and, when activated, would be expected to increase cAMP levels. Therefore, we reasoned that VIP could be a ligand in the SCN that maintains the peak VP transcription. Therefore, we compared the effects of VIP with forskolin and with another neurotransmitter, serotonin, known to be present in the SCN (Ueda et al., 1983; Pickard and Rea, 1997) on $c$-fos expression in the cultured SCN. Figure 2 illustrates the effects of applying $0.3 \mu \mathrm{M}$ VIP, $10 \mu \mathrm{M}$ forskolin, or $10 \mu \mathrm{M}$ serotonin on c-fos expression in the cultured SCN in TTX. All three of these reagents evoked fos expression at the concentrations used.

After "free-running" in vitro for $17 \mathrm{~d}, \mathrm{VP}$ neurons in organotypically cultured SCNs exhibit circadian rhythms of VP gene expression, with a peak transcription rate (VP hnRNA levels) occurring at approximately 12:00 P.M. (Arima et al., 2002). Typical c-Fos-IR and VP hnRNA levels in the cultured SCN are shown in Figure 3, $A$ and $B$, respectively, for this peak time period. Changes in the $\mathrm{c}-$ fos and VP expression patterns as a result of inhibition by TTX (Fig. 3C,D) and a strong depolarizing stimulus, $50 \mathrm{~mm} \mathrm{KCl} \mathrm{(Fig.}$ $3 E, F)$ in the presence of TTX, are illustrated in Figure 3. Under 

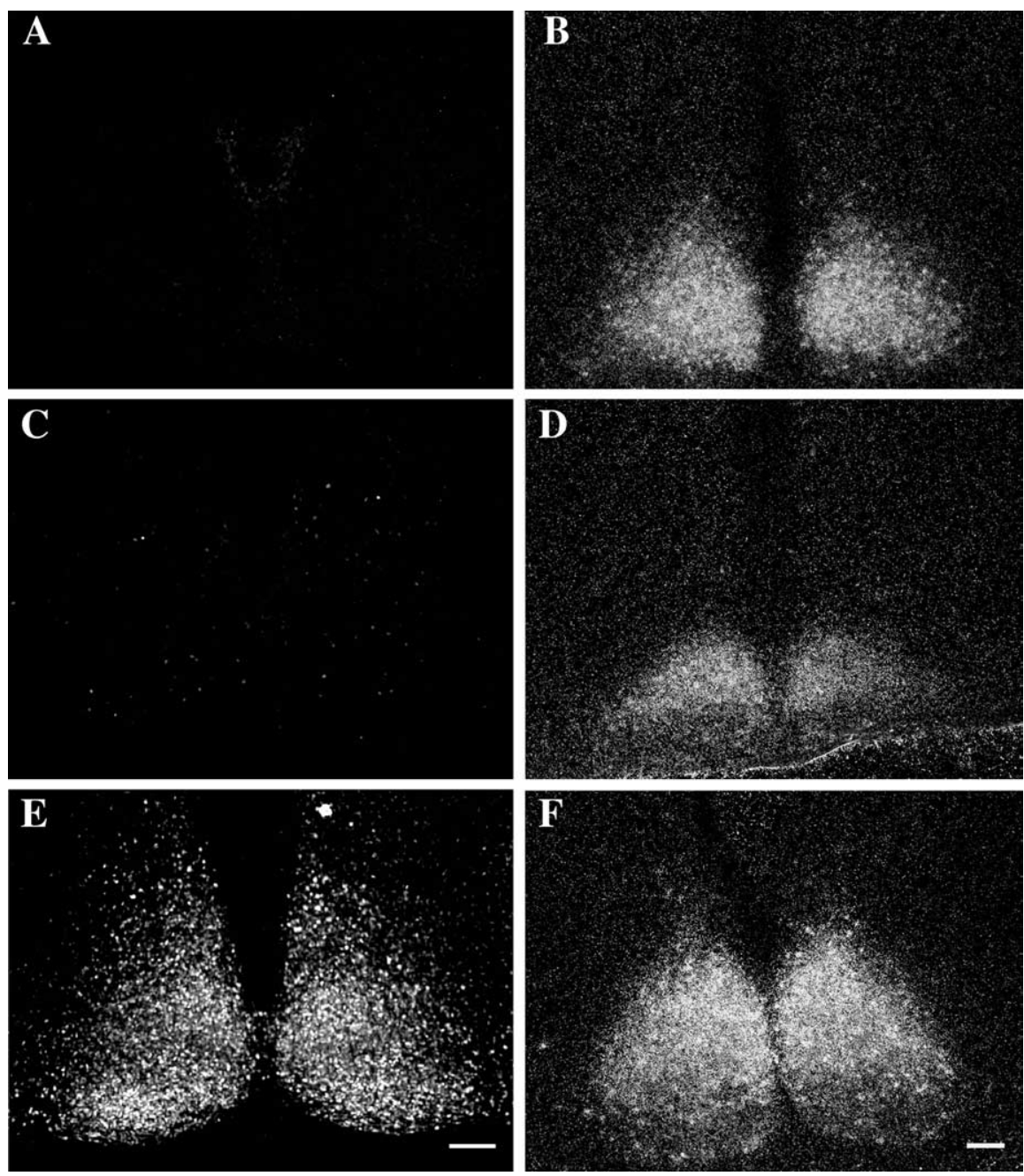

Figure 3. Illustrations of typical patterns of $C-F$ os-IR $(\boldsymbol{A}, \boldsymbol{C}, \boldsymbol{E})$ and VP hnRNA expression $(\boldsymbol{B}, \boldsymbol{D}, \boldsymbol{F})$ in SCN slice explants after $17 \mathrm{~d}$ of organotypic culture, in control slices $(\boldsymbol{A}, \boldsymbol{B})$, in the presence of $2.5 \mu \mathrm{MTX}$ for $3 \mathrm{~h}(\boldsymbol{C}, \boldsymbol{D})$, and in slices depolarized for $2 \mathrm{~h}$ by $50 \mathrm{~mm}$ potassium chloride in the presence of TTX $(\boldsymbol{E}, \boldsymbol{F})$. For details, see Results. Scale bars: $\boldsymbol{E}$ and $\boldsymbol{F}$ represent $100 \mu \mathrm{m}$ for $\boldsymbol{A}, \boldsymbol{C}, \boldsymbol{E}$ and $\boldsymbol{B}, \boldsymbol{D}$, respectively.

control conditions, there was little c-Fos-IR evident in the SCN (Fig. $3 A$ ), and this was not altered by the application of TTX (Fig. 3C). However, $50 \mathrm{~mm} \mathrm{KCl}$ depolarization for $2 \mathrm{~h}$ (in the presence of TTX) produced a robust c-fos expression throughout the SCN (Fig. 3E). The substantial VP hnRNA expression in the control SCN (Fig. 3B) was significantly decreased by the TTX treatment (Fig. 3D), confirming previous observations (Arima et al., 2002), and the potassium depolarization of the cells in the SCN produced a significant increase in the VP hnRNA level (Fig. 3F) in the presence of TTX. In the experiments that follow, we systematically evaluate the changes in VP hnRNA (see Materials and Methods) in the cultured SCN under these and other pharmacological perturbations.

\section{VP gene expression is linked to neural activity in the cultured SCN}

It is well known that there is an increased outgrowth and activity of GABAergic fibers in organotypic brain slice cultures that results in a large overall increased inhibition attributable to hyperactivation of $\mathrm{GABA}_{\mathrm{A}}$ receptors (Bali and Kovacs, 2003). Hence, application of the $\mathrm{GABA}_{\mathrm{A}}$ antagonist bicuculline produces robust excitation in these cultures (Bali and Kovacs, 2003). We found that this bicuculline treatment similarly causes a large increase in VP gene expression (VP
hnRNA), $\sim 175 \%$ of values in control cultures in the absence of TTX (Fig. 4, CON, BICUC). The data in Figure 4 are expressed as percentages of the control levels, which are set at $100 \%$. These data clearly show that spontaneous neural activity represents a significant variable in the expression of the VP gene in the cultured SCN slice. Consequently, any effects on VP gene expression in this in vitro system caused by pharmacological interventions in the absence of TTX could be indirect via GABAergic or other unknown synaptic afferents. Therefore, in the neurotransmitter and other pharmacological experiments that follow, we use the TTX as a tool to block all spontaneous electrical and evoked synaptic activity to establish a baseline of the VP hnRNA levels in the SCN. Hence, all of the subsequent responses to pharmacological treatment can be interpreted as acting directly on the VP neurons in the SCN.

In the experiment shown in Figure 4, in which all of the manipulations illustrated were done on SCN cultures after 17 div, application of the TTX produced a large decrease in VP gene expression in $2 \mathrm{~h}$, and, as expected, bicuculline in the presence of TTX had no effect (data not shown). However, application of either 10 $\mu \mathrm{M}$ forskolin or $50 \mathrm{~mm} \mathrm{KCl}$ for $2 \mathrm{~h}$ reversed the TTX inhibition of the VP gene expression (Fig. 4). Overall, these data support the hypothesis that VP gene expression in the SCN is directly influenced by neural activity and suggest that the neural activity inhibited in TTX can be mimicked by either cAMP generation (by forskolin treatment) or by $\mathrm{KCl}$-induced depolarization. In the experiments that follow, we use pharmacological approaches to explore the mechanisms that might underlie these distinct methods to rescue the VP gene expression in TTX.

\section{VIP activation of the VPAC2 receptor reverses the inhibition of VP gene expression by TTX}

Because the inhibition of VP gene expression in the SCN could be reversed by the application of forskolin to the slice preparation (Fig. 4), this suggested that the neural input to the VP neurons in the SCN that is responsible for the activation of VP transcription might be acting via a G-protein-coupled receptor to increase intracellular cAMP. The two main candidate ligands known to be present in the SCN and that can generate cAMP by activation of the G-protein-coupled receptors are VIP and PACAP-38 (Moore et al., 2002). Therefore, we compared VIP, PACAP-38, and serotonin, all able to evoke c-fos expression in the SCN (Fig. 2), for their relative effectiveness in reversing the TTX inhibition of the VP gene expression in the cultured SCN. These data, illustrated in Figure 5 show that VIP is the most efficacious ligand, producing nearly a threefold increase in VP hnRNA over the TTX-treated SCN. The serotonin did not significantly change the VP hnRNA level, and the PACAP-38 ligand was considerably less potent than the VIP. 


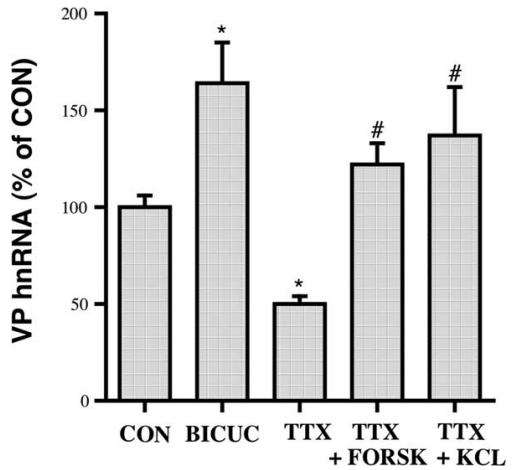

Figure 4. Effects of $10 \mu \mathrm{m}$ bicuculline and $2.5 \mu \mathrm{m}$ TTX on VP hnRNA levels in the SCN in vitro and the stimulation of VP gene expression in TTX by the addition of either $10 \mu \mathrm{m}$ forskolin (FORSK) or $50 \mathrm{~mm} \mathrm{KCl} \mathrm{to} \mathrm{the} \mathrm{culture} \mathrm{medium.} \mathrm{Data} \mathrm{are} \mathrm{expressed} \mathrm{as} \mathrm{mean} \pm$ SEM percentage of integrated optical density over $S C N$ in control slices. $n=19,9,27,10$, and 5 for the control (CON), bicuculline (BICUC), TTX, TTX plus forskolin, and TTX plus KCl groups, respectively. ${ }^{*} p<$ 0.05 versus control group; $\#<0.05$ versus TTX-treated group. Statistical differences were calculated by ANOVA, followed by Fisher's PLSD test.

The data presented in Figure 6 are consistent with the view that the most likely neurotransmitter candidate to mimic the forskolin effect on the SCN is VIP acting through the VPAC2 receptor. As can be seen in Figure 6, VIP, forskolin, and the VPAC2 receptor-specific ligand Ro-25-1553 (Gourlet et al., 1997; Moreno et al., 2000; Reed et al., 2002; Cutler et al., 2003) all produce very large and comparable increases in VP hnRNA over the TTX-treated SCN. It is interesting to note that adding VIP plus forskolin together in the media did not increase the VP hnRNA over that of obtained by stimulation with either VIP or forskolin alone (Fig. 6). Similar data were obtained with copresentation of the Ro-25-1553 and the forskolin to the SCN in vitro. These data therefore suggest that the VIP, Ro-25-1553, and forskolin stimuli share the same signal-transduction cascade pathway. The fact that the MEK inhibitor PD98059 inhibits the stimulatory action of VIP (Fig. 6) on VP gene expression suggests that this increase primarily involves activation of the MAP kinase pathway. Figure 7 reinforces this view by showing that the forskolin reversal of the TTX on VP gene expression is inhibited by PD98059 but not statistically significantly by the protein kinase A inhibitor H89. Furthermore, the inhibition of the forskolin stimulation of VP gene expression was equivalent when the PD90859 and $\mathrm{H} 89$ were used together compared with the application of the PD90859 used alone.

\section{Membrane depolarization and calcium ion influx reverse the TTX inhibition of VP gene expression}

As noted in Figure 4, depolarization of the SCN neurons by increasing external potassium ion in the medium produced a reversal of the TTX inhibition of VP hnRNA levels comparable with that produced by forskolin. Figure 8 compares this increase in VP hnRNA produced by $\mathrm{KCl}$ depolarization with that of other depolarizing stimuli, that is the application of various ionotropic glutamate receptor ligands, AMPA, kainate, and NMDA. Although two of the ionotropic ligands, kainate and NMDA, produced statistically significant increases in VP hnRNA over the TTXtreated SCN, these increases were substantially lower than that produced by the $\mathrm{KCl}$-induced depolarization. The AMPA ionotropic receptor ligand and the metabotropic glutamate receptor ligand DHPG did not significantly affect the VP gene expression compared with the TTX control (Fig. 8). This suggests that membrane depolarization per se is the effective stimulus and that, if

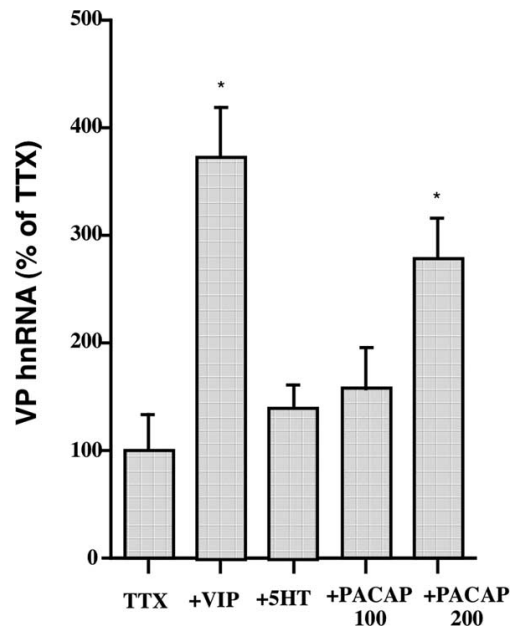

Figure 5. Comparison of the effects of neurotransmitters that are present in the SCN on VP hnRNA expression in the presence of TTX. Effects of the exposure of the SCN in vitro to $0.3 \mu \mathrm{M}$ VIP, $10 \mu$ m serotonin (5HT), or 100-200 nM PACAP-38 on VP hnRNA levels in the SCN compared with TTX controls are shown. Data are expressed as mean \pm SEM percentage of integrated optical density over SCN in control slices, in which $n=27,15,5,4$, and 4 for the TTX, VIP, serotonin, $100 \mathrm{~nm}$ PACAP, and $200 \mathrm{~nm}$ PACAP groups, respectively. ${ }^{*} p<0.05$ versus the TTX control. Statistical differences were calculated by ANOVA, followed by Fisher's PLSD test.

this is the case, then a calcium mechanism might also be involved. The finding that kainate but not AMPA produced a small but significant increase in VP hnRNA in the cultured SCN could be related to the lower desensitization rate found to exist in response to stimulation of ionotropic glutamate receptors by kainate as opposed to AMPA agonists (Fletcher and Lodge, 1996).

Figure 9 presents data indicating that calcium influx through the cell membrane plays a critical role in the $\mathrm{KCl}$-stimulated increase in VP gene expression in TTX. This is indicated by the large decrease in VP hnRNA produced by cadmium ion (Fig. 9, Cd), a general inhibitor of voltage-sensitive calcium channels, and also by nimodipine (Fig. 9, NIMO), a specific inhibitor of the L-type, voltage-activated calcium channel. The reduction of VP hnRNA by cadmium ion was significantly greater than that of nimodipine, raising the possibility that other calcium channel subtypes might also play a role in the depolarization-induced VP transcription in the SCN. In contrast, thapsigargin, which reduces the mobilization of intracellular calcium, did not have any statistically significant effect on VP hnRNA levels during the potassium depolarization, indicating that extracellular rather than intracellular calcium ion mobilization is involved in the potassium depolarization-induced transcription. Consistent with this role for calcium ion in the regulation of VP gene expression by depolarization is the observation shown in Figure 9 that KN62, a general inhibitor of CaMKs (Davies et al., 2000), also significantly inhibited the increase in VP hnRNA levels caused by the $\mathrm{KCl}$ stimulus. In contrast, neither KN93, a highly specific inhibitor of CaMKII (Atkins et al., 2004), nor its inactive analog KN92 produced any inhibition of the $\mathrm{KCl}$-induced increase in VP gene expression (data not shown). This suggests that a calciumdependent kinase other than CaMKII is involved, possibly CaMKIV, which is known to be inhibited by KN62 (MarinBriggiler et al., 2005). It is interesting that the highly specific MEK inhibitor PD98059 also inhibited the $\mathrm{KCl}$ depolarizationinduced increase in VP gene expression in TTX (Fig. 9). This implies that both calcium-dependent and MAP kinase pathways in the VP neurons of the SCN are involved in the depolarizationinduced increase in VP gene expression. In other experiments, we 


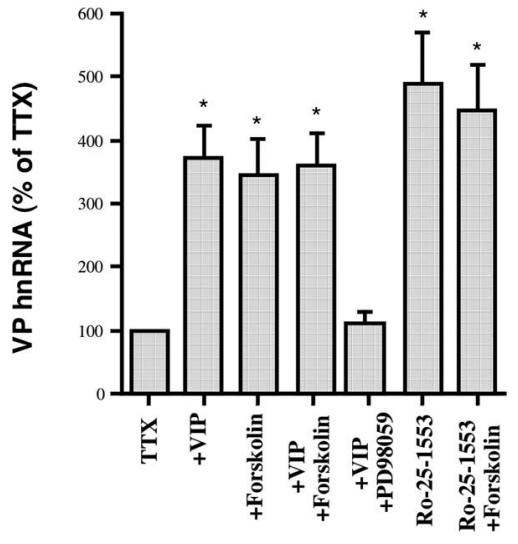

Figure 6. The effect of VIP on VP hnRNA gene expression in the $\mathrm{SCN}$ occurs by activation of a VPAC2 receptor and an MAP kinase signaling pathway. Both $0.3 \mu \mathrm{M}$ VIP and the VPAC2 receptor-specific agonist, $100 \mathrm{~nm}$ Ro-25-1553, are highly effective in stimulating VP gene expression in the SCN in the presence of TTX. The addition of $10 \mu \mathrm{m}$ forskolin together with either of these agonists does not produce an additive effect. Data are expressed as mean \pm SEM percentage of integrated optical density over SCN in TTX-treated slices, in which $n=17,15,5$, $7,4,12$, and 3 for the TTX, VIP, forskolin, VIP plus PD98059, VIP plus forskolin, Ro-25-1553, and Ro-25-1553 plus forskolin groups, respectively. ${ }^{*} p<0.05$ versus the TTX control. Statistical differences were calculated by ANOVA, followed by Fisher's PLSD test.

found that the combined application of the PD98059 and KN62 inhibitors did not increase the inhibition of the depolarization induced increase in VP hnRNA over that obtained when these inhibitors were applied alone (data not illustrated). This suggests that both the calcium-dependent and cAMP-dependent pathways are required to achieve the activity-dependent peak of VP gene expression in the SCN.

\section{Regulation of VP gene expression in the SCN involves two signal-transduction pathways}

The experimental perturbations described above, performed in the presence of TTX, suggest that there are two signal transduction pathways required to increased VP gene expression in the SCN. These are (1) a VIP input via a VPAC2 receptor, leading to increased CAMP- and an MAP-kinase-dependent pathway and/or (2) depolarizing stimuli (presumably normal spiking activity), leading in turn to calcium influx through voltageactivated calcium channels and subsequent activation of a CaMK pathway. The question arises whether the inhibitors of these signal transduction pathways would mimic the effect of TTX on the free running SCN in culture to inhibit the peak VP gene transcription (Fig. 4) (Arima et al., 2002). To evaluate this, we compared the effects of the key pharmacological agents on VP gene expression in the otherwise unperturbed cultured SCN after 17 div and at approximately 12:00 P.M., when the VP expression is at its maximum (Arima et al., 2002). The results of this experiment are shown in Figure 10, in which these calcium- and cAMPrelated inhibitory agents are all shown to inhibit the maximum daily VP expression to the same extent as TTX. All three calciumrelated inhibitors, cadmium ion, nimodipine, and KN62, as well as the cAMP inhibitor Rp-8-Br-cAMPS (Gjertsen et al., 1995; Calaghan et al., 1999), and two different MEK inhibitors PD98059 and UO126 produced a decrease in VP gene expression to $50 \%$ of the unperturbed control. Thus, we conclude that the diurnal regulation of the VP gene in the SCN involves the contributions of two independent signal transduction cascades, a calcium- and a cAMP-dependent pathway. We were unable to unequivocally demonstrate that activation of the VPAC2 recep-

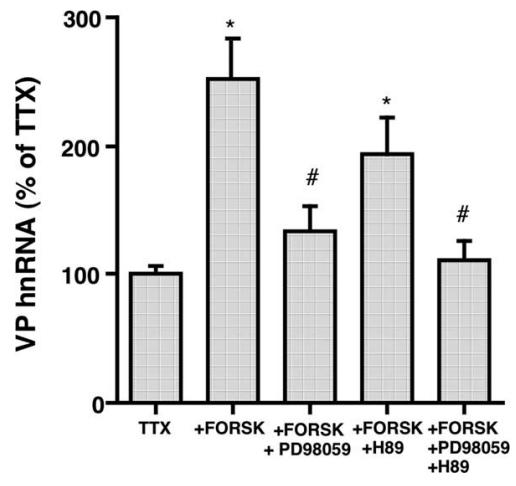

Figure 7. Effects of $10 \mu \mathrm{m}$ forskolin, $5 \mu \mathrm{m}$ H89 (PKA inhibitor), or the MEK inhibitor PD98059 $(75 \mu \mathrm{M})$ on forskolin-induced increases of VP hnRNA in the SCN in vitro. In all of these experiments, the medium contained $2.5 \mu \mathrm{m}$ TTX. Data are expressed as means \pm SEM percentage of integrated optical density over SCN in TTX-treated slices. ${ }^{*} p<0.05$ versus TTX-treated group. $n=27,15,6,7$, and 7 for the TTX, forskolin (FORSK), forskolin plus PD98059, forskolin plus H89, and forskolin plus PD98059 plus $\mathrm{H89}$ groups, respectively. $\# p<0.05$ versus forskolin-treated group. Statistical differences were calculated by ANOVA, followed by Fisher's PLSD test. Note that PD98059 but not $\mathrm{H} 89$ inhibited the forskolin-induced increase in VP hnRNA.

tor was the cause of the increased cAMP associated with the peak VP gene expression at 12:00 P.M., because the specific VPAC2 antagonist, $100 \mathrm{nM}$ PG-99-465, did not produce a statistically significant decrease in VP hnRNA (data not shown). Raising the amount of the PG-99-465 revealed that it behaved as a partial agonist at the higher concentration (also found in studies of cell lines transfected with VPAC2 receptors; P. Robberecht, personal communication), thereby preventing a resolution of this issue by use of this antagonist. However, some supporting evidence for this hypothesis is the fact that the VPAC1 receptor antagonist PACAP-6-38, was able to inhibit the VP gene expression but only at $>5 \mu \mathrm{M}$ concentrations (data not shown), at which it is known to also inhibit the VPAC2 receptor (Dickinson and FleetwoodWalker, 1999).

\section{Discussion}

We reported previously that the SCN in organotypic culture exhibits a robust circadian rhythm in VP gene transcription and that TTX reduced the daytime peak to nighttime levels (Arima et al., 2002), suggesting that ongoing interneuronal activity in the $\mathrm{SCN}$ is required for the maintenance of the peak of VP transcription. This TTX inhibition of VP transcription could be reversed by forskolin, further suggesting that activation of a G-proteincoupled receptor linked to adenylate cyclase might be responsible for this neural activity-dependent VP transcription. In this paper, we examine the hypothesis that VIP acting on VPAC2 receptors on the VP cells is the critical ligand responsible for maintaining peak VP transcription in the SCN.

We adopted the following strategies. First, we use organotypic cultures, which are excellent models for the study of circadian rhythms in the SCN (Arima et al., 2002; Maywood et al., 2006), to allow strict control of the environment of the SCN and to eliminate the influence of distant afferent inputs. Second, pharmacological studies are performed in the presence of TTX to isolate the VP neurons from any evoked synaptic activity. Third, we use an intron-specific probe for VP in the ISHH analysis (Herman et al., 1991; Arima et al., 2002) that can detect rapid changes in VP gene expression. Finally, we use c-Fos-IR in IHC as an assay to ensure that the concentrations of candidate ligands used were adequate to activate receptors in the SCN. The experimental conditions and neurotransmitter ligands that we studied, e.g., glutamate, 


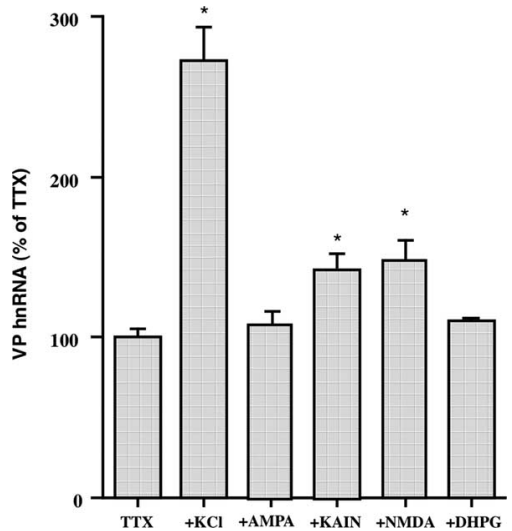

Figure 8. Comparisons of the effects of $50 \mathrm{~mm}$ potassium depolarization (KCI) and various glutamate agonists [50 $\mu$ M NMDA, AMPA, kainate (KAIN), or DHPG] on VP hnRNA levels in the SCN in the presence of TTX. Data are expressed as means \pm SEM percentage of integrated optical density over SCN in control slices. $n=27,5,4,4,4$, and 4 for the TTX, KCl, AMPA, kainate, NMDA, and DHPG groups, respectively. ${ }^{*} p<0.05$ versus control. Statistical differences were calculated by ANOVA, followed by Fisher's PLSD test.

serotonin, VIP, and depolarization, induce c-fos gene expression in the SCN in vivo (Hastings et al., 1997; Schurov et al., 1999; Hannibal, 2002) and in vitro (Figs. 1-3).

\section{Neural activity-dependent signals leading to VP gene transcription}

Two types of data lead us to link neural activity to VP gene transcription. The first is that TTX treatment of the SCN culture inhibited VP gene transcription (Arima et al., 2002). The second is that bicuculline, presumably causing excitation by disinhibiting the GABAergic input in the cultured organotypic slice, produced a large increase in VP gene transcription (Fig. 4).

\section{VIP and the VPAC2 receptor regulate VP gene transcription} Experiments performed in TTX support the hypothesis that VIP activating the VPAC2 receptor maintains VP gene transcription at peak levels. Evidence for this are that only the VIP peptide and the VPAC2 receptor-specific ligand Ro-25-1553 produce increases in VP transcription in TTX that are equivalent to that produced by forskolin, VIP, Ro-25-1553, and forskolin produced the same effect when applied alone or together (Fig. 6), suggesting that these stimuli are using the same signal transduction pathways. We reported previously that the MEK-MAP kinase pathway is involved in stimulating VP transcription in the SCN during peak expression, because it was inhibited (in the absence of TTX) by the MEK inhibitor PD98059 but not the PKA inhibitor H89 (Arima et al., 2002). Consistent with this, the forskolin stimulation (in TTX) of VP transcription is similarly inhibited by PD98059 but not by H89 (Fig. 7). Several other laboratories have also found prominent roles for MAP kinase mechanisms in the SCN (Obrietan et al., 1999; Dziema et al., 2003; Coogan and Piggins, 2004).

VIP and the VPAC2 receptor are known to be critical regulators of synchronized circadian rhythms in the SCN. Knock-out of the VPAC2 receptor gene (Vipr2) in mice (Harmar et al., 2002) showed that this null mutation profoundly effected the circadian rhythms of expression of clock genes [mPer1 (mouse period 1), mPer2 (mouse period 2), and Cry1 (crytochrome 1)], the clockcontrolled VP gene, and various other circadian functions in the SCN (Cutler et al., 2003; Aton and Herzog, 2005; Aton et al., 2005; Maywood et al., 2006). VIP acting through the VPAC2

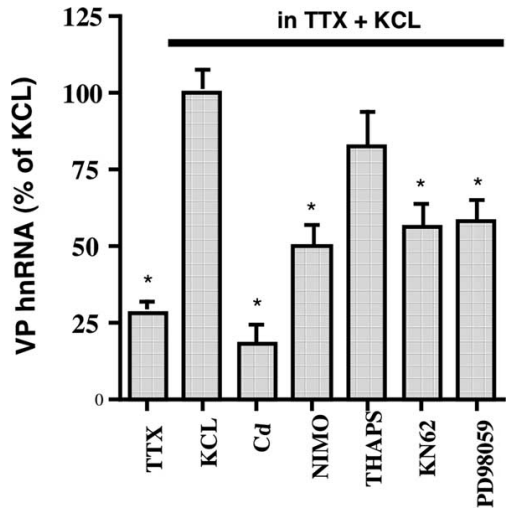

Figure 9. Effects of inhibition of extracellular and intracellular sources of calcium release and selective kinase inhibitors on the increase of VP hnRNA produced by $50 \mathrm{~mm} \mathrm{KCl}$ depolarization. All treatments were in the presence of TTX in the media. Inhibition of calcium channels by the nonspecific calcium channel blocker, $200 \mu \mathrm{m}$ cadmium ion (Cd), and the specific L-type calcium channel blocker, $5 \mu \mathrm{m}$ nimodipine (NIMO), significantly decreased the VP hnRNA levels in the SCN during potassium depolarization. In contrast, there was no reduction in the VP hnRNA levels by application of $0.2 \mu \mathrm{m}$ thapsigargin (THAPS). Both the $60 \mu \mathrm{m}$ KN62 (CaMK kinase) inhibitor and the $75 \mu \mathrm{M}$ PD98059 (MEK kinase) inhibitor significantly inhibited the KCl-induced increase in VP hnRNA expression. Data are expressed as mean \pm SEM percentage of integrated optical density over SCN in KCL stimulated slices. $n=9,20,8,8,11$, and 10 for the TTX, KCl, Cd, nimodipine, KN62, and PD 980959 groups, respectively. ${ }^{*} p<0.05$ decrease value versus $\mathrm{KCl}$. Statistical differences were calculated by ANOVA, followed by Fisher's PLSD test.

receptor produces cAMP, which undergoes diurnal fluctuations (Ferreyra and Golombek, 2000), and which correlates with circadian variations in levels of activated forms of the transcription factor phosphorylated cAMP response element-binding protein (P-CREB) (Obrietan et al., 1999). Elevated cAMP levels could influence VP gene expression through the CREB/cAMP response element (CRE) transcriptional pathway because the VP gene promoter region contains a putative CRE site (Burbach et al., 2001). This transcriptional pathway is activated by multiple kinases such as, PKA, $\mathrm{Ca}^{2+} /$ calmodulin-dependent kinase, and MAP kinase (Gonzalez and Montminy, 1989; Sheng et al., 1991; Xing et al., 1996). In this regard, inhibition of PKA by H89 had no effect on the forskolin-induced VP gene transcription in the presence of TTX in the SCN, but the MAP kinase pathway inhibitor PD98059 reduced it to the control (TTX) level. There was no quantitative difference between the effects of the PD98059 used alone or together with the H89, indicating that there was no significant contribution of the PKA pathway. PD98059 was also shown to reduce VP gene transcription to a very low level during the day in the absence of TTX treatment (Arima et al., 2002). These data are consistent with the hypothesis that VIP acting through the VPAC2 receptor is responsible for the daytime elevation in VP hnRNA level in vitro by activating adenylate cyclase and MAP kinase but not via PKA. Whether the MAP kinase pathway acts via P-CREB or through other transcriptional factors is still unclear. The VP gene promoter contains not only a CRE site but an activator protein-1 site and five E box enhancers as well (Burbach et al., 2001).

\section{Depolarization-induced calcium ion signals regulate VP transcription}

In the course of our studies, we found that potassium depolarization was as effective as a stimulus of VP gene transcription in the SCN in TTX as was forskolin (Fig. 4). This suggested that there might also be a depolarization-evoked, presumably calcium iondependent, pathway that could increase VP gene transcription in 


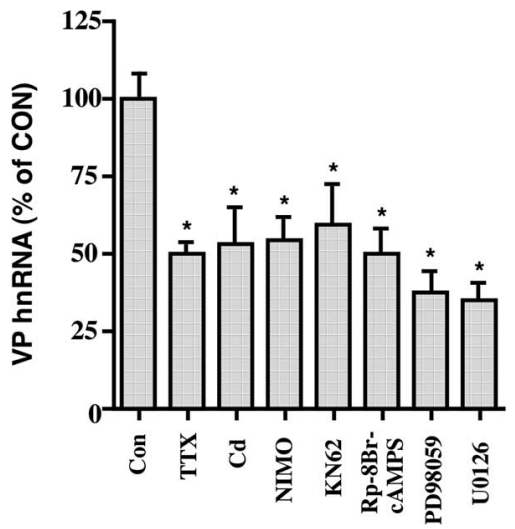

Figure 10. Pharmacological tests of the hypothesis that both calcium-dependent and cAMP/MAP kinase-dependent pathways are involved in the peak of VP gene expression in the SCN. During the peak time of VP gene expression in the SCN in vitro (in the absence of TTX), the following reagents produced inhibition of VP hnRNA expression equivalent to that produced by $2.5 \mu \mathrm{m}$ TTX (Con). The reagents included a nonspecific calcium channel blocker, $200 \mu \mathrm{m}$ cadmium ion (Cd), a specific L-type calcium channel blocker, $5 \mu$ m nimodipine (NIMO), the CaMK inhibitor, $60 \mu \mathrm{m}$ KN62, the cell-permeable cAMP inhibitor, $200 \mu \mathrm{M} \mathrm{Rp}$-Br -CAMPS, the MAPK kinase pathway (MEK) inhibitors, $75 \mu \mathrm{M}$ PD 980959 and $10 \mu \mathrm{m}$ U0126; all decreased SCN VP hnRNA levels. Significant changes in VP hnRNA levels were found for all of the treatments shown compared with the untreated control. Data are expressed as means \pm SEM percentage of integrated optical density over SCN in control slices (equal to 100\%). $n=19,27,6,6,10,15$, 6, and 5 for the control, TTX, Cd, nimodipine, KN62, Rp-8-Br-CAMPS, PD98059, and U0126 groups, respectively. ${ }^{*} p<0.05$ versus control. Statistical differences were calculated by ANOVA, followed by Fisher's PLSD test.

TTX. It should be noted here that the extent and synchrony of spike activity in the SCN are highly regulated by the VPAC2 receptor and are dysregulated in the Vipr $2^{-/-}$SCN (Reed et al., 2002; Cutler et al., 2003; Piggins and Cutler, 2003; Aton and Herzog, 2005; Aton et al., 2005; Pakhotin et al., 2006). Therefore, these two mechanisms are not entirely independent. Nevertheless, it is interesting that the loss of the VPAC2 receptor causes substantial hyperpolarization in SCN neurons and a correlated decrease in mPer gene expression (Lundkvist et al., 2005).

There are two mechanisms by which depolarization can influence the VP neurons, synaptic and direct electrical (spike) activity. We examined ionotropic glutamate receptor agonists and found that the cultured SCN was quite responsive with regard to their ability to evoke c-Fos-IR responses (Fig. 1) in TTX. Interestingly, this was also true in response to the metabotropic glutamate agonist (Fig. $1 E$ ). However, in TTX, the glutamate agonists either had no significant effect or only a small effect on VP gene transcription compared with the larger increase by potassium depolarization (Fig. 8). These data suggest that direct depolarization or spike activity (in the absence of TTX) was the likely mechanism, possibly through a calcium ion-dependent signal transduction pathway. The effect of potassium depolarization to increase VP gene transcription in TTX that was blocked by inhibitors of calcium ion influx through voltage-gated calcium channels (Fig. 9, Cd, nimodipine) is consistent with this hypothesis and with reports describing voltage-gated calcium channels as an important factor in the regulation of circadian rhythms in the SCN (Pennartz et al., 2002; Lundkvist et al., 2005; Pakhotin et al., 2006). Inhibition by the CaM general protein kinase inhibitor (KN62) but not by a specific CaM protein kinase II inhibitor (KN93) suggests that this signal transduction pathway might use CaM IV (Obrietan et al., 2002). Interestingly, this effect of the potassium depolarization stimulus was also blocked by the MEK inhibitor PD98059, and the combined application of the

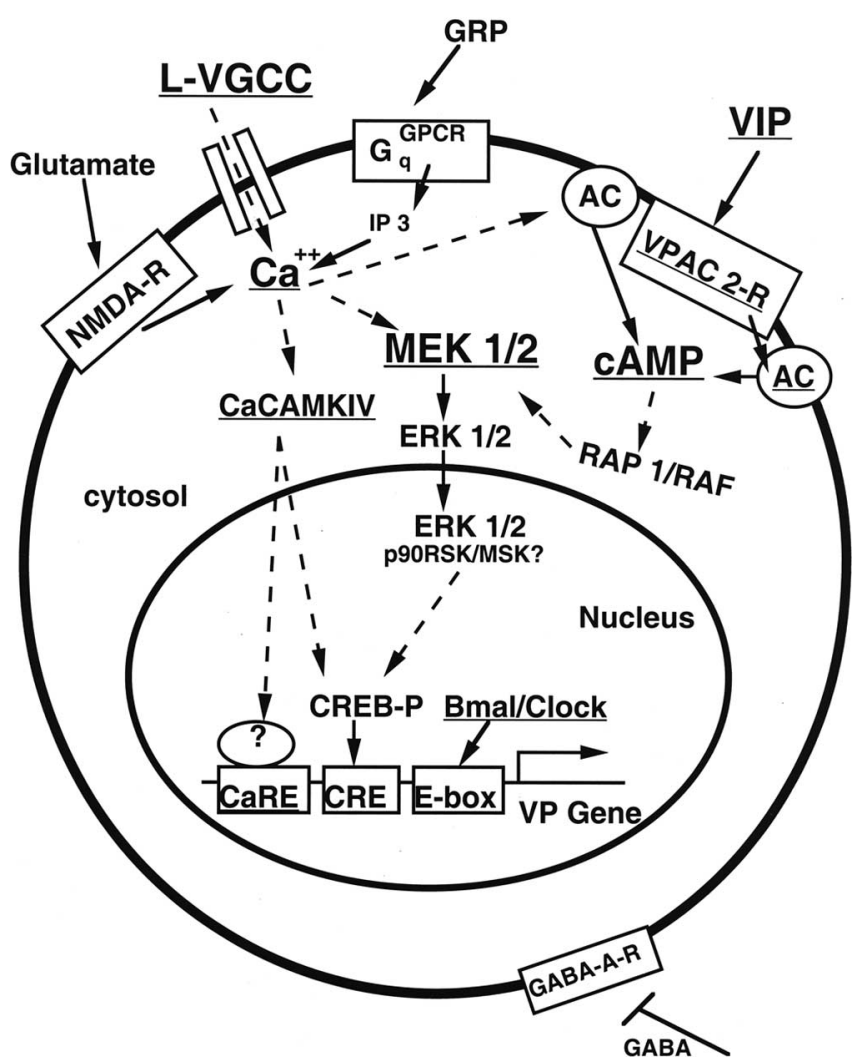

Figure 11. Model of regulation of vasopressin gene expression in the SCN. A schematic representation of potential neurotransmitter ligands and receptors in the VP cell membrane, signal transduction mechanisms, and kinase pathways that are linked to VP gene expression in the $\mathrm{SCN}$ is shown. The molecular components and mechanisms that are critical and are supported by pharmacological data presented in this paper are underlined. Two distinct signal transduction cascades are involved: (1) membrane depolarization leading to Ca influx through L-type Ca channels activates both CaMK and MAP kinase pathways, and (2) VIP activation of the VPAC2 receptors on VP neurons is coupled to adenylate cyclase $(A C)$ generation of CAMP, which results in the activation of the MAP kinase pathway. Underlined words and filled arrows depict processes supported by data in this paper or in the literature [e.g., for Bmal/Clock (Jin et al., 1999)], and arrows with dotted lines represent speculative processes. The downstream regulatory component is hypothesized to be phosphorylated CREB and/or unknown activators (?) of not yet identified elements. The temporal pattern of VP expression in the SCN is considered as requiring both a circadian oscillatory component (Bmal/Clock) to open the gate (Ebox) and a neural activity component (VIP and/or spikes) to drive the VP expression (possibly via the CRE) of the VP gene. VGCC, Voltage-gated calcium channel; GPCR, G-protein-coupled receptor; ERK, extracellular signal-regulated kinase; RSK, ribosomal S6 kinase; MSK, mitogen- and stressactivated kinase 1; CaRE, calcium response element; GRP, gastin releasing peptide.

PD98059 and KN62 inhibitors did not increase the inhibition of the depolarization-induced increase in VP gene transcription over that obtained when these inhibitors were applied alone, thereby suggesting possible interactions between the two kinase pathways.

Signal transduction pathways and VP transcription in the absence of TTX

Experiments on the SCN in TTX lead us to a dualistic view of the regulation of VP gene transcription in TTX, by both a VIPcAMP-MAP kinase pathway and a depolarization calcium ion influx-CaMK pathway. The data in Figure 10 test this dualistic view by examining the effects on VP gene transcription of all of the inhibitors of the specific components in these two pathways in the absence of TTX. These inhibitors inhibited VP gene transcription to the same extent as the TTX did. This is consistent 
with the hypothesis that neural activity affects VP gene transcription by activation of each of these pathways. Because KN62 and PD98059 (and U0126) inhibitors when used alone had similar effects as TTX suggests that these two pathways may be acting in a cooperative manner to regulate VP gene transcription. A summary of this view is illustrated in Figure 11.

\section{References}

Antle MC, Foley DK, Foley NC, Silver R (2003) Gates and oscillators: a network model of the brain clock. J Biol Rhythms 18:339-350.

Arima H, House SB, Gainer H, Aguilera G (2002) Neuronal activity is required for the circadian rhythm of vasopressin gene transcription in the suprachiasmatic nucleus in vitro. Endocrinology 143:4165-4171.

Atkins CM, Nozaki N, Shigeri Y, Soderling TR (2004) Cytoplasmic polyadenylation element binding protein-dependent protein synthesis is regulated by calcium/calmodulin-dependent protein kinase II. J Neurosci 24:5193-5201.

Aton SJ, Herzog ED (2005) Come together, right.now: synchronization of rhythms in a mammalian circadian clock. Neuron 48:531-534.

Aton SJ, Colwell CS, Harmar AJ, Waschek J, Herzog ED (2005) Vasoactive intestinal polypeptide mediates circadian rhythmicity and synchrony in mammalian clock neurons. Nat Neurosci 8:476-483.

Bali B, Kovacs KJ (2003) GABAergic control of neuropeptide gene expression in parvocellular neurons of the hypothalamic paraventricular nucleus. Eur J Neurosci 18:1518-1526.

Ben-Barak Y, Russell JT, Whitnall MH, Ozato K, Gainer H (1985) Neurophysin in the hypothalamo-neurohypophysial system. I. Production and characterization of monoclonal antibodies. J Neurosci 5:81-97.

Burbach JP, Luckman SM, Murphy D, Gainer H (2001) Gene regulation in the magnocellular hypothalamo-neurohypophysial system. Physiol Rev 81:1197-1267.

Calaghan SC, Colyer J, White E (1999) Cyclic AMP but not phosphorylation of phospholamban contributes to the slow inotropic response to stretch in ferret papillary muscle. Pflügers Arch 437:780-782.

Coogan AN, Piggins HD (2004) MAP kinases in the mammalian circadian system-key regulators of clock function. J Neurochem 90:769-775.

Cutler DJ, Haraura M, Reed HE, Shen S, Sheward WJ, Morrison CF, Marston HM, Harmar AJ, Piggins HD (2003) The mouse VPAC2 receptor confers suprachiasmatic nuclei cellular rhythmicity and responsiveness to vasoactive intestinal polypeptide in vitro. Eur J Neurosci 17:197-204.

Davies SP, Reddy H, Caivano M, Cohen P (2000) Specificity and mechanism of action of some commonly used protein kinase inhibitors. Biochem J 351:95-105.

Dickinson T, Fleetwood-Walker SM (1999) VIP and PACAP: very important in pain? Trends Pharmacol Sci 20:324-329.

Dziema H, Oatis B, Butcher GQ, Yates R, Hoyt KR, Obrietan K (2003) The ERK/MAP kinase pathway couples light to immediate-early gene expression in the suprachiasmatic nucleus. Eur J Neurosci 17:1617-1627.

Eyigor O, Centers A, Jennes L (2001) Distribution of ionotropic glutamate receptor subunit mRNAs in the rat hypothalamus. J Comp Neurol 434:101-124.

Ferreyra GA, Golombek DA (2000) Cyclic AMP and protein kinase A rhythmicity in the mammalian suprachiasmatic nuclei. Brain Res 858:33-39.

Fletcher EJ, Lodge D (1996) New developments in the molecular pharmacology of alpha-amino-3-hydroxy-5-methyl-4-isoxazole propionate and kainate receptors. Pharmacol Ther 70:65-89.

Gillette MU, Tischkau SA (1999) Suprachiasmatic nucleus: the brain's circadian clock. Recent Prog Horm Res 54:33-58; discussion 58-39.

Gjertsen BT, Mellgren G, Otten A, Maronde E, Genieser HG, Jastorff B, Vintermyr OK, McKnight GS, Doskeland SO (1995) Novel (Rp)cAMPS analogs as tools for inhibition of cAMP-kinase in cell culture. Basal cAMP-kinase activity modulates interleukin-1 beta action. J Biol Chem 270:20599-20607.

Gonzalez GA, Montminy MR (1989) Cyclic AMP stimulates somatostatin gene transcription by phosphorylation of CREB at serine 133. Cell 59:675-680.

Gourlet P, Vertongen P, Vandermeers A, Vandermeers-Piret MC, Rathe J, De Neef P, Waelbroeck M, Robberecht P (1997) The long-acting vasoactive intestinal polypeptide agonist RO 25-1553 is highly selective of the VIP2 receptor subclass. Peptides 18:403-408.

Hannibal J (2002) Neurotransmitters of the retino-hypothalamic tract. Cell Tissue Res 309:73-88.
Harmar AJ, Marston HM, Shen S, Spratt C, West KM, Sheward WJ, Morrison CF, Dorin JR, Piggins HD, Reubi JC, Kelly JS, Maywood ES, Hastings MH (2002) The VPAC(2) receptor is essential for circadian function in the mouse suprachiasmatic nuclei. Cell 109:497-508.

Hastings MH, Duffield GE, Ebling FJ, Kidd A, Maywood ES, Schurov I (1997) Non-photic signalling in the suprachiasmatic nucleus. Biol Cell 89:495-503.

Herman JP, Schafer MK, Watson SJ, Sherman TG (1991) In situ hybridization analysis of arginine vasopressin gene transcription using intronspecific probes. Mol Endocrinol 5:1447-1456.

House SB, Thomas A, Kusano K, Gainer H (1998) Stationary organotypic cultures of oxytocin and vasopressin magnocellular neurones from rat and mouse hypothalamus. J Neuroendocrinol 10:849-861.

Ingram CD, Snowball RK, Mihai R (1996) Circadian rhythm of neuronal activity in suprachiasmatic nucleus slices from the vasopressin-deficient Brattleboro rat. Neuroscience 75:635-641.

Ingram CD, Ciobanu R, Coculescu IL, Tanasescu R, Coculescu M, Mihai R (1998) Vasopressin neurotransmission and the control of circadian rhythms in the suprachiasmatic nucleus. Prog Brain Res 119:351-364.

Jin X, Shearman LP, Weaver DR, Zylka MJ, de Vries GJ, Reppert SM (1999) A molecular mechanism regulating rhythmic output from the suprachiasmatic circadian clock. Cell 96:57-68.

Kalsbeek A, Buijs RM (2002) Output pathways of the mammalian suprachiasmatic nucleus: coding circadian time by transmitter selection and specific targeting. Cell Tissue Res 309:109-118.

Lundkvist GB, Kwak Y, Davis EK, Tei H, Block GD (2005) A calcium flux is required for circadian rhythm generation in mammalian pacemaker neurons. J Neurosci 25:7682-7686.

Ma XM, Aguilera G (1999) Transcriptional responses of the vasopressin and corticotropin-releasing hormone genes to acute and repeated intraperitoneal hypertonic saline injection in rats. Brain Res Mol Brain Res 68:129-140.

Marin-Briggiler CI, Jha KN, Chertihin O, Buffone MG, Herr JC, VazquezLevin MH, Visconti PE (2005) Evidence of the presence of calcium/ calmodulin-dependent protein kinase IV in human sperm and its involvement in motility regulation. J Cell Sci 118:2013-2022.

Maywood ES, Reddy AB, Wong GK, O’Neill JS, O’Brien JA, McMahon DG, Harmar AJ, Okamura H, Hastings MH (2006) Synchronization and maintenance of timekeeping in suprachiasmatic circadian clock cells by neuropeptidergic signaling. Curr Biol 16:599-605.

Moore RY, Silver R (1998) Suprachiasmatic nucleus organization. Chronobiol Int 15:475-487.

Moore RY, Speh JC, Leak RK (2002) Suprachiasmatic nucleus organization. Cell Tissue Res 309:89-98.

Moreno D, Gourlet P, De Neef P, Cnudde J, Waelbroeck M, Robberecht P (2000) Development of selective agonists and antagonists for the human vasoactive intestinal polypeptide $\operatorname{VPAC}(2)$ receptor. Peptides 21:1543-1549.

Morin LP, Allen CN (2006) The circadian visual system, 2005. Brain Res Brain Res Rev 51:1-60.

Morin LP, Shivers KY, Blanchard JH, Muscat L (2006) Complex organization of mouse and rat suprachiasmatic nucleus. Neuroscience 137:1285-1297.

Mutsuga N, Shahar T, Verbalis JG, Brownstein MJ, Xiang CC, Bonner RF, Gainer H (2004) Selective gene expression in magnocellular neurons in rat supraoptic nucleus. J Neurosci 24:7174-7185.

Mutsuga N, Shahar T, Verbalis JG, Xiang CC, Brownstein MJ, Gainer H (2005) Regulation of gene expression in magnocellular neurons in rat supraoptic nucleus during sustained hypoosmolality. Endocrinology 146:1254-1267.

Obrietan K, Impey S, Smith D, Athos J, Storm DR (1999) Circadian regulation of cAMP response element-mediated gene expression in the suprachiasmatic nuclei. J Biol Chem 274:17748-17756.

Obrietan K, Gao XB, Van Den Pol AN (2002) Excitatory actions of GABA increase BDNF expression via a MAPK-CREB-dependent mechanism-a positive feedback circuit in developing neurons. J Neurophysiol 88:1005-1015.

Pakhotin P, Harmar AJ, Verkhratsky A, Piggins H (2006) VIP receptors control excitability of suprachiasmatic nuclei neurones. Pflügers Arch 452:7-15.

Pennartz CM, de Jeu MT, Bos NP, Schaap J, Geurtsen AM (2002) Diurnal 
modulation of pacemaker potentials and calcium current in the mammalian circadian clock. Nature 416:286-290.

Perreau-Lenz S, Pevet P, Buijs RM, Kalsbeek A (2004) The biological clock: the bodyguard of temporal homeostasis. Chronobiol Int 21:1-25.

Pickard GE, Rea MA (1997) Serotonergic innervation of the hypothalamic suprachiasmatic nucleus and photic regulation of circadian rhythms. Biol Cell 89:513-523.

Piggins HD, Cutler DJ (2003) The roles of vasoactive intestinal polypeptide in the mammalian circadian clock. J Endocrinol 177:7-15.

Reed HE, Cutler DJ, Brown TM, Brown J, Coen CW, Piggins HD (2002) Effects of vasoactive intestinal polypeptide on neurones of the rat suprachiasmatic nuclei in vitro. J Neuroendocrinol 14:639-646.

Reppert SM, Weaver DR (2001) Molecular analysis of mammalian circadian rhythms. Annu Rev Physiol 63:647-676.

Reppert SM, Weaver DR (2002) Coordination of circadian timing in mammals. Nature 418:935-941.

Rusnak M, Gainer H (2005) Differential effects of forskolin on tyrosine hydroxylase gene transcription in identified brainstem catecholaminergic neuronal subtypes in organotypic culture. Eur J Neurosci 21:889-898.

Schurov IL, McNulty S, Best JD, Sloper PJ, Hastings MH (1999) Glutamatergic induction of CREB phosphorylation and Fos expression in primary cultures of the suprachiasmatic hypothalamus in vitro is mediated by co-ordinate activity of NMDA and non-NMDA receptors. J Neuroendocrinol 11:43-51.
Sheng M, Thompson MA, Greenberg ME (1991) CREB: a $\mathrm{Ca}^{2+}$-regulated transcription factor phosphorylated by calmodulin-dependent kinases. Science 252:1427-1430.

Shibata S, Moore RY (1993) Tetrodotoxin does not affect circadian rhythms in neuronal activity and metabolism in rodent suprachiasmatic nucleus in vitro. Brain Res 606:259-266.

Ueda S, Kawata M, Sano Y (1983) Identification of serotonin and vasopressin immunoreactivities in the suprachiasmatic nucleus of four mammalian species. Cell Tissue Res 234:237-248.

Usdin TB, Bonner TI, Mezey E (1994) Two receptors for vasoactive intestinal polypeptide with similar specificity and complementary distributions. Endocrinology 135:2662-2680.

Watson Jr RE, Wiegand SJ, Clough RW, Hoffman GE (1986) Use of cryoprotectant to maintain long-term peptide immunoreactivity and tissue morphology. Peptides 7:155-159.

Xing J, Ginty DD, Greenberg ME (1996) Coupling of the RAS-MAPK pathway to gene activation by RSK2, a growth factor-regulated CREB kinase. Science 273:959-963.

Yamaguchi S, Isejima H, Matsuo T, Okura R, Yagita K, Kobayashi M, Okamura H (2003) Synchronization of cellular clocks in the suprachiasmatic nucleus. Science 302:1408-1412.

Yambe Y, Arima H, Kakiya S, Murase T, Oiso Y (2002) Diurnal changes in arginine vasopressin gene transcription in the rat suprachiasmatic nucleus. Brain Res Mol Brain Res 104:132-136. 